University of Nebraska - Lincoln

DigitalCommons@University of Nebraska - Lincoln

USGS Staff -- Published Research

US Geological Survey

2015

Sediment and discharge yields within a minimally disturbed, headwater watershed in North Central Pennsylvania, USA, with an emphasis on Superstorm Sandy

Kelly O. Maloney

U.S. Geological Survey, Leetown Science Center, Northern Appalachian Research Laboratory, kmaloney@usgs.gov

Dustin R. Shull

Pennsylvania Department of Environmental Protection

Follow this and additional works at: http://digitalcommons.unl.edu/usgsstaffpub

Part of the Earth Sciences Commons, Environmental Sciences Commons, and the Oceanography and Atmospheric Sciences and Meteorology Commons

Maloney, Kelly O. and Shull, Dustin R., "Sediment and discharge yields within a minimally disturbed, headwater watershed in North Central Pennsylvania, USA, with an emphasis on Superstorm Sandy" (2015). USGS Staff -- Published Research. 857.

http:// digitalcommons.unl.edu/usgsstaffpub/857

This Article is brought to you for free and open access by the US Geological Survey at DigitalCommons@University of Nebraska - Lincoln. It has been accepted for inclusion in USGS Staff -- Published Research by an authorized administrator of DigitalCommons@University of Nebraska - Lincoln. 


\title{
Sediment and discharge yields within a minimally disturbed, headwater watershed in North Central Pennsylvania, USA, with an emphasis on Superstorm Sandy
}

\author{
Kelly O. Maloney ${ }^{1}$ \& Dustin R. Shull ${ }^{2}$ \\ ${ }^{1}$ U.S. Geological Survey, Leetown Science Center, Northern Appalachian Research Laboratory, Wellsboro, PA 16901 and ${ }^{2}$ Pennsylvania Department of
} Environmental Protection, Harrisburg, PA 17101

\section{Keywords}

hurricane; hysteresis; runoff; small streams; storm event; turbidity.

\section{Correspondence}

Kelly O. Maloney, U.S. Geological Survey, Leetown Science Center, Northern Appalachian Research Laboratory, Wellsboro, PA 16901.Email: kmaloney@usgs.gov

doi:10.1111/wej.12113

\begin{abstract}
We estimated discharge and suspended sediment (SS) yield in a minimally disturbed watershed in North Central Pennsylvania, USA, and compared a typical storm (September storm, $4.80 \mathrm{~cm}$ ) to a large storm (Superstorm Sandy, $7.47 \mathrm{~cm}$ rainfall). Depending on branch, Sandy contributed 9.7-19.9 times more discharge and 11.5-37.4 times more SS than the September storm. During the September storm, the upper two branches accounted for $60.6 \%$ of discharge and $88.8 \%$ of SS at Lower Branch; during Sandy these percentages dropped to 36.1\% for discharge and $30.1 \%$ for SS. The branch with close proximity roads had over two-three times per area SS yield than the branch without such roads. Hysteresis loops showed typical clockwise patterns for the September storm and more complicated patterns for Sandy, reflecting the multipeak event. Estimates of SS and hysteresis in minimally disturbed watersheds provide useful information that can be compared spatially and temporally to facilitate management.
\end{abstract}

\section{Introduction}

Within a watershed, sediment export varies spatially and temporally. Various mechanisms have been identified that drive this variability, including rainfall characteristics, soil moisture and historic rainfall, land use, soil surface conditions, sediment availability, distance from sediment source and the dominant sediment generating process (Steegen et al. 2000; Giménez et al. 2012; Gellis 2013). Depending on spatial position in the watershed, season and antecedent climate conditions (i.e. precipitation), the relative contribution of these factors change. Human actions also alter sediment budgets in watersheds. For example, unpaved roads and road and stream crossings are sources of sediment (Reid \& Dunne 1984; Lane \& Sheridan 2002) and agriculture is a large nonpoint source of sediment (Pimental et al. 1995; USDA 2011). This anthropogenic modification of the sediment budget makes it difficult to quantify natural patterns in sediment yield, which is important information for managers.

Storm events carry the majority of suspended sediment (SS) in streams (Wolman \& Miller 1960; Webb \& Walling 1982). With increasing rainfall intensity (both amount and rate) more sediment is delivered from upslope watersheds to receiving streams and transported within streams. Major storms, such as hurricanes, produce large amounts of high intensity rainfall, which results in large amounts of runoff and sediment delivery to streams. Moreover, extremely high discharges resulting from these storms create greater potential of in-channel transport of sediment (Leopold et al. 1964). This potential is heightened in headwaters systems, because of their greater slope (typically) and increased proximity to source waters.

During storms, SS and discharge relationships often exhibit a hysteretic loop, whose patterns can be used to indicate the relative sources or processes of SS. For example, clockwise hysteresis patterns infer depletion of available sediment in watersheds or stream channels, reduced erosive effect of precipitation, or increased proportion of baseflow during receding limb of hydrographs (Williams 1989; Gellis 2013). Counterclockwise or eight-shaped hysteresis patterns, however, indicate high intensity precipitation, multiple peak storms, flood waves that traveled faster than mean flow velocity, increased bank erosion or an input of distant sediment sources (Williams 1989; Nadal-Romero et al. 2008). Anthropogenic disturbance, such as unpaved roads, alter these patterns (Wang et al. 2013), thus there is potential to use hysteresis loops to assess changes in SS from anthropogenic stressors.

We measured discharge and SS loads (or concentrations) during two storms (one being Superstorm Sandy) for three main branches in a small, minimally disturbed, second-order 
watershed in North Central Pennsylvania. Superstorm Sandy made landfall in mid-Atlantic portion of the US on 29 October 2012 as a very large 'hybrid' storm that resembled a large winter-like Nor'easter with a distinct tropical core (Blake et al. 2013; Halverson and Rabenhorst 2013). Sandy had the lowest recorded sea-level atmospheric pressure recorded north of the Carolinas in the United States and was the largest recorded tropical cyclone (Blake et al. 2013). Sandy also caused a large storm surge into the New Jersey and New York coastlines and resulted in large rainfall and snowfall events in the mid-Atlantic interior (Blake et al. 2013). One objective was to compare levels of discharge and sediment exported during Sandy to a smaller storm that occurred about a month earlier. We also evaluated relative contributions of each branch and storm event to overall discharge and sediment yields. Although current anthropogenic disturbance is limited to unpaved forest roads, this watershed is scheduled for unconventional oil and gas development, which entails creation of unpaved roads and pipelines. Thus, another goal was to document predevelopment storm hysteresis loops to identify sediment sources under undisturbed conditions.

\section{Study site}

Canada Run is a small, second-order watershed in the upper Chesapeake Bay drainage basin that drains $11.6 \mathrm{~km}^{2}$ in Tioga County, Pennsylvania, USA (Fig. 1). The watershed largely resides in Pennsylvania State Forest lands and has limited anthropogenic disturbance (unpaved forest roads and periodic silviculture activities). Streams are largely dominated by riffle-pool sequences with beds mostly consisting of large cobble and boulders. Drainage areas above sampling sites were $4.26 \mathrm{~km}^{2}$ for the upper branch of Canada Run (Upper Branch), $2.99 \mathrm{~km}^{2}$ for the East Branch Canada Run (East Branch) and $9.89 \mathrm{~km}^{2}$ for the lower branch of Canada Run (Lower Branch). Upper Branch had $5.8 \mathrm{~km}$ of unpaved roads in its watershed $\left(1.3 \mathrm{~km} / \mathrm{km}^{2}\right)$ and Lower branch had $8.9 \mathrm{~km}$ of unpaved roads $\left(0.9 \mathrm{~km} / \mathrm{km}^{2}\right)$, both with a portion in close proximity to streams (Fig. 1). East Branch had $2.5 \mathrm{~km}$ of unpaved roads in its watershed $\left(0.8 \mathrm{~km} / \mathrm{km}^{2}\right)$, most were located in its upper slopes. As a result of low human influence, stream channels showed minimal evidence of bank erosion and incision.

The first storm, September Storm, occurred 18 to $19 \mathrm{Sep}$ tember and yielded $4.80 \mathrm{~cm}$ of rainfall and the second storm, Superstorm Sandy, occurred 29 to 31 October and yielded $7.47 \mathrm{~cm}$ (rainfall amounts from rain gage at the US Geological Survey Northern Appalachian Research Laboratory, Wellsboro, PA, USA). Examination of long-term daily rainfall totals from a nearby weather station (near Wellsboro, PA GHCND:USC00369408, 1 January 1926 to 13 January 2014) showed these rainfall totals were near the upper limits of storm events over this 88 year period (Appendix Fig. A1).

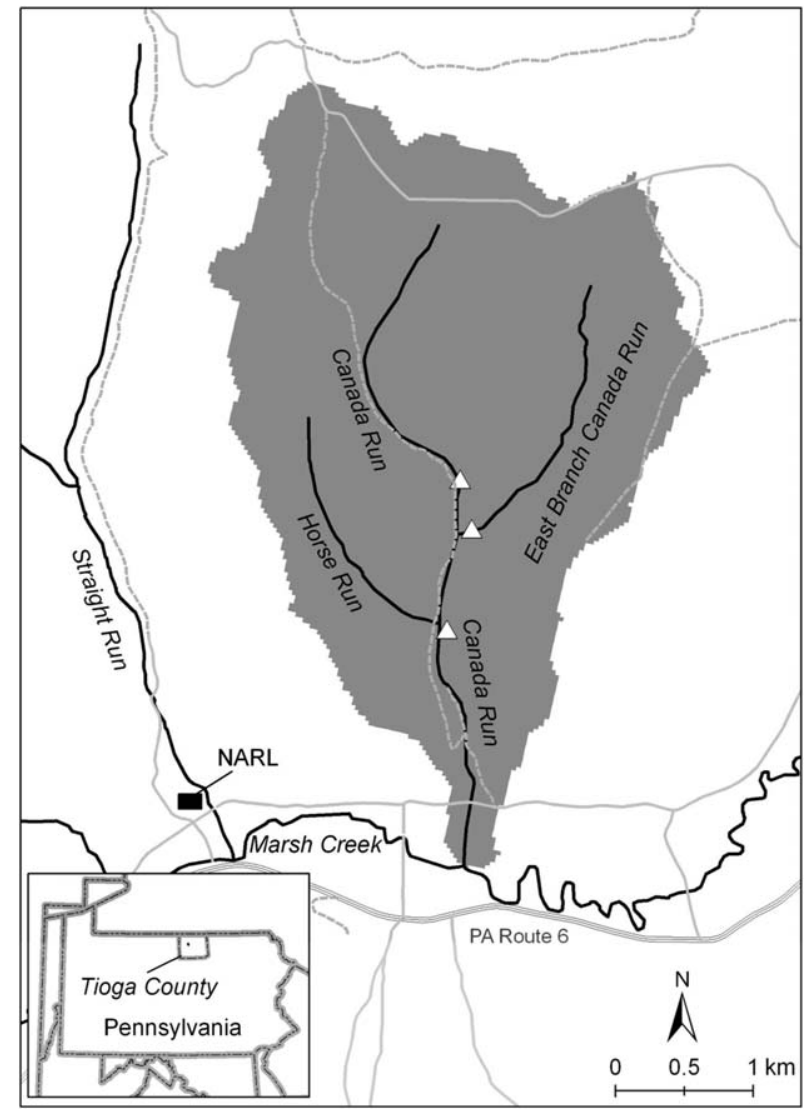

Fig. 1. Map showing location of Canada Run watershed. Solid thin gray lines indicate township roads, dashed thin gray lines indicate unpaved forest roads, tripled gray line indicates paved state road. Triangles represent site locations. Black rectangle shows location of the US Geological Survey Northern Appalachian Research Laboratory (NARL), Wellsboro, PA, USA. Inset shows location in relation to US state of Pennsylvania.

\section{Methods}

Height and turbidity (YSI 6136 turbidity probe) data were measured at 15 min intervals using data sondes (YSI 6920 V2 at Lower Branch, YSI 6600 V2 at other two branches) from 0:00 16 August 2012 to 23:45 16 November 2012. To quantify discharge, we developed height:discharge relationships for each stream following Rasmussen et al. (2009). Discharge was measured nine times at Upper Branch and eight times at East and Lower Branches (Table 1, Fig. 2). For total SS, grab samples (1L) were taken during discharge measurements for suspended sediment concentration (SSC). Additional SSC samples (500-600 mL) were taken during storms using automated samplers (Teledyne ISCO model 6712, Lincoln, Nebraska, USA; See Appendix Table A1 for a list of samples). SS was estimated following the methods of Rasmussen et al. (2009). Our final analysis examined hysteresis patterns in SSC:Discharge relationships. Here, we plotted SSC versus discharge for the September event and Superstorm Sandy. All 
Table 1 Yields of suspend sediment (SS) and total discharge for entire study period and for the September and Sandy storms

\begin{tabular}{|c|c|c|c|c|c|c|}
\hline Site & Variable & September Storm & Sandy & Total & $\begin{array}{l}\text { Percent Sept. } \\
\text { Storm of Total }\end{array}$ & $\begin{array}{l}\text { Percent } \\
\text { Sandy of Total }\end{array}$ \\
\hline \multirow[t]{5}{*}{ East Branch } & Number records (days) & $145(1.5)$ & $371(3.9)$ & $8913(92.8)$ & & \\
\hline & Number discharge readings & 4 & 4 & & & \\
\hline & Total Discharge $\left(\mathrm{m}^{3}\right)$ & 2377 & 38774 & 99084 & 2.4 & 39.1 \\
\hline & Peak flow $\left(\mathrm{m}^{3} / \mathrm{s}\right)^{\mathrm{a}}$ & 0.15 & 0.62 & & & \\
\hline & Total SS (kg) & 74 & 852 & 955 & 7.8 & 89.3 \\
\hline \multirow[t]{5}{*}{ Upper Branch } & Number records (days) & $145(1.5)$ & $371(3.9)$ & 8915 (92.9) & & \\
\hline & Number discharge readings & 5 & 4 & & & \\
\hline & Total Discharge $\left(\mathrm{m}^{3}\right)$ & 4942 & 48059 & 105151 & 4.7 & 45.7 \\
\hline & Peak flow $\left(\mathrm{m}^{3} / \mathrm{s}\right)^{\mathrm{a}}$ & 0.20 & 1.20 & & & \\
\hline & Total SS (kg) & 288 & 3739 & 4151 & 6.9 & 90.1 \\
\hline \multirow[t]{5}{*}{ Lower Branch } & Number records (days) & $144(1.5)$ & $371(3.9)$ & 8927 (93) & & \\
\hline & Number discharge readings & 4 & 4 & & & \\
\hline & Total Discharge $\left(\mathrm{m}^{3}\right)$ & 12075 & 240328 & 443515 & 2.7 & 54.2 \\
\hline & Peak flow $\left(\mathrm{m}^{3} / \mathrm{s}\right)^{\mathrm{a}}$ & 0.56 & 7.53 & & & \\
\hline & Total SS (kg) & 407 & 15231 & 16134 & 2.5 & 94.4 \\
\hline \multicolumn{2}{|c|}{$\begin{array}{l}\text { Percent of flow accounted at the Lower } \\
\text { site by the two upper reaches: }\end{array}$} & 60.6 & 36.1 & 46.0 & & \\
\hline \multicolumn{2}{|c|}{$\begin{array}{l}\text { Percent of SS accounted at the Lower } \\
\text { site by the two upper reaches: }\end{array}$} & 88.8 & 30.1 & 31.6 & & \\
\hline
\end{tabular}

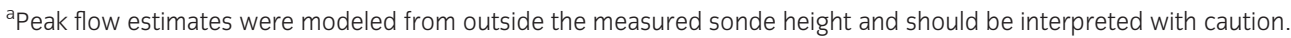

statistical analyses were conducted using R (R Development Core Team 2013).

\section{Results and discussion}

All discharge-height regression models were significant $(P<0.05)$ and fit the data well (Appendix Table A2). Using these curves, we estimated, over the entire study, East Branch discharged $99084 \mathrm{~m}^{3}$ (33 $\left.138 \mathrm{~m}^{3} / \mathrm{km}^{2}\right)$, Upper branch

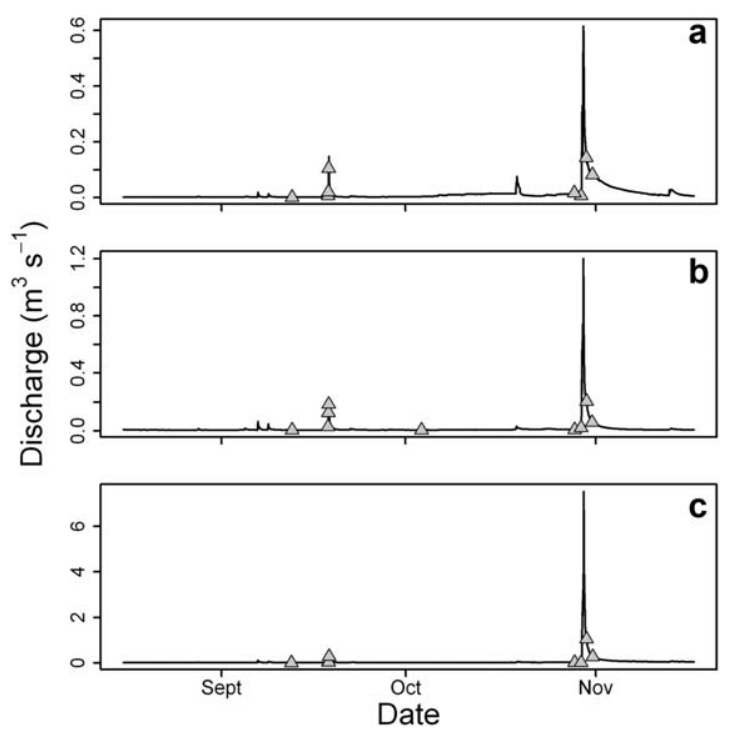

Fig. 2. Discharge $\left(\mathrm{m}^{3} / \mathrm{s}\right)$ plotted against date. Gray triangles indicate dates discharge and grab suspended samples were taken. (a) East Branch (b) Upper Branch and (c) Lower Branch. discharged $105151 \mathrm{~m}^{3}\left(24683 \mathrm{~m}^{3} / \mathrm{km}^{2}\right)$ and Lower Branch discharged $443515 \mathrm{~m}^{3}\left(44845 \mathrm{~m}^{3} / \mathrm{km}^{2}\right.$; Table 1). The upper two branches accounted for $46.0 \%$ of discharge at Lower Branch. SSC and turbidity relationships also were strong (Appendix Table A3; Appendix Fig. A2). Using these curves, over the entire study, East Branch yielded $955 \mathrm{~kg}\left(319 \mathrm{~kg} / \mathrm{km}^{2}\right)$ SS, Upper Branch yielded $4151 \mathrm{~kg}\left(975 \mathrm{~kg} / \mathrm{km}^{2}\right)$ SS, and lower branch yielded $16134 \mathrm{~kg}\left(1631 \mathrm{~kg} / \mathrm{km}^{2}\right)$ SS (Table 1).

During the September storm the two upper branches accounted for $60.6 \%$ of total discharge, $12075 \mathrm{~m}^{3}\left(1221 \mathrm{~m}^{3}\right.$ ) $\mathrm{km}^{2}$ ), from Lower Branch, whereas during Sandy they accounted for only $36.1 \%$ of total discharge at Lower Branch, $240328 \mathrm{~m}^{3}$ (24 $300 \mathrm{~m}^{3} / \mathrm{km}^{2}$, Table 1). Compared to the September storm, Sandy yielded $1531 \%$ more water in East Branch, $873 \%$ more water in Upper Branch, and $1890 \%$ more water in Lower Branch. Superstorm Sandy yielded 39.1, 45.7 and $54.2 \%$ of total discharge in the East, Upper and Lower Branches, respectively. These temporal differences in discharge yield were likely driven by differences in rainfall, soil moisture and surface conditions, and antecedent rainfall as well as evapotranspiration. First, Superstorm Sandy locally resulted in $\sim 1.6 \times$ as much rainfall as the September storm $(7.47$ vs. $4.80 \mathrm{~cm})$, which undoubtedly led to more runoff. However, the September storm also occurred during full leaf out and was preceded by a week with little precipitation (previous 7 days $0.38 \mathrm{~cm}$ rainfall). Superstorm Sandy occurred after leaf fall and the preceding week had $1.60 \mathrm{~cm}$ of rainfall. So, during the September storm, soils were drier and a large proportion of rainfall was likely lost because of evapotranspiration, which might be a reason for the 9.7 to 19.9 fold 
Fig. 3. Suspended sediment concentration (SSC) versus discharge during the September storm (Left panels) and Superstorm Sandy (Right Panels). (a) East Branch, September storm, (b) East Branch, Superstorm Sandy, (c) Upper Branch, September storm, (d) Upper Branch, Superstorm Sandy, (e) Lower Branch, September storm and (f) Lower Branch, Superstorm Sandy. All hysteric loops for the September storm exhibit a clockwise pattern (a, c, e; highlighted by the gray arrows), whereas all figures for Sandy exhibit more complex patterns (b, $d, f)$.
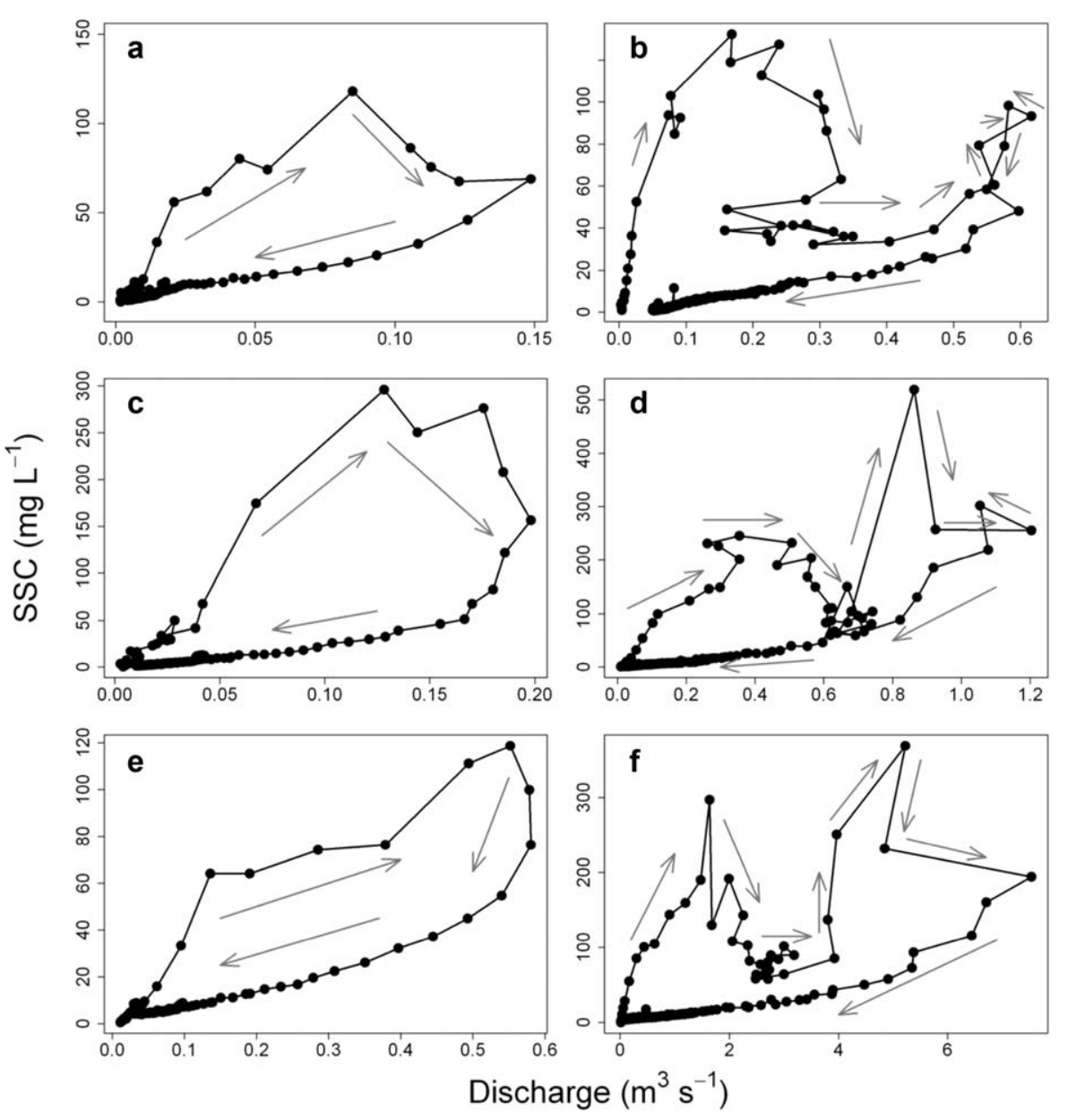

higher discharge and 4.1 to 13.4 larger peak flows during Superstorm Sandy (cf. September storm).

During the September storm the two upper branches accounted for $88.8 \%$ of total SS exported at Lower Branch for the September storm $\left(407 \mathrm{~kg}\left(41 \mathrm{~kg} / \mathrm{km}^{2}\right)\right)$, whilst during Sandy they accounted for $30.1 \%$ of SS yield at Lower Branch (15 $231 \mathrm{~kg}$ (1540 kg/km²); Table 1). Percent increases in SS yield from Sandy compared to the September storm were 1047, 1200 and 3638\% for East Branch, Upper Branch and Lower Branch, respectively. Superstorm Sandy yielded 89.3, 90.1 and $94.4 \%$ of total SS yield in the East, Upper and Lower Branches, respectively. We examined SS yield during two storms at a very small scale (three branches in a single, small, minimally disturbed watershed). Thus, for a single storm most factors driving SS export should be similar. However, land use (unpaved roads) and distance to outlet, two factors that varied among subwatersheds, likely drove the spatial differences in SS yield. All subwatersheds were completely forested; however, Lower Branch and Upper Branch had an unpaved road in close proximity to streams (Fig. 1). These unpaved roads were a likely reason behind the greater than two-three times per area SS yield in Upper
Branch than East Branch during both storms (68 vs. 25 kg/ $/ \mathrm{km}^{2}$ for September storm; 878 vs. $285 \mathrm{~kg} / \mathrm{km}^{2}$ for Superstorm Sandy). Unpaved roads have often been reported to increase SS yields (Reid \& Dunne 1984). It is likely that higher rain intensity during Sandy also mobilized more watershed sediment. Moreover, the higher discharges during Sandy may have moved more channel sediment than what occurred during the September storm. Upper Branch and East Branch also contributed a substantially lower proportion of discharge and SS to Lower Branch during Sandy. This was likely because of the third, and smallest, first-order tributary (Horse Run, Fig. 1) contributing a larger volume of water (and sediment) during Sandy (K. Maloney, USGS, personal observation).

All three branches showed clockwise hysteresis patterns during the September storm (Fig. 3), suggesting sediment was available during rising limbs of the event, possibly from in-channel storage, with source sediment depletion or increased proportion of groundwater in receding limbs of hydrographs (Williams 1989; Gellis 2013). For Superstorm Sandy, however; all sites showed clockwise patterns initially but then showed 'second' clockwise patterns (Fig. 3). Upper and East Branches showed weak counterclockwise patterns 
mid-way through the second storm pulse. The preliminary clockwise patterns may be Sandy initially acting as a 'normal' storm in a minimally disturbed watershed and experiencing source sediment depletion. However, Superstorm Sandy had multiple peaks in its hydrograph (see Appendix Fig. A3), suggesting a cessation of rainfall followed by a second storm pulse. The short-term counterclockwise patterns during the second pulse indicates this part of the storm may have had a flood wave that traveled faster than mean flow velocity, increased bank erosion or an input of distant sediment sources. However, these sources only lasted briefly as hysteresis curves again turned clockwise during the latter part of the second pulse, once again indicating source sediment depletion. High intensity, multipeak SS storms, like Sandy, often result in eight-shaped hysteresis curves (Nadal-Romero et al. 2008). Our hysteresis curves for Sandy, especially for Upper and East Branches, approached eight-shape patterns but this pattern never clearly materialized, possibly indicating rainfall intensities were not overly intense during this storm or that this forested watershed was capable of handling the water and energy of Sandy. Comparison of these minimally disturbed hysteresis loops to future post development hysteresis loops may aid identification of sediment sources resulting from associated construction (e.g. roads, Wang et al. 2013).

Here, we showed that a large storm (Superstorm Sandy) contributed a 9.7 to 19.9 times higher amount of discharge and 11.5 to 37.4 times the amount of sediment than a storm half its size that occurred a month earlier. These results highlight the high potential of large storms similar to Superstorm Sandy to move large amounts of sediment. Moreover, our results suggest that the presence of unpaved roads in a watershed may increase SSs in streams, especially if the roads are close to the streams. Data such as these may better inform land managers when incorporating best management practices for unpaved roads. Highlighting the significant differences between these two storms in sediment output may help guide future decisions on how to better maintain and ultimately improve watershed response to large storms. Our watershed also was located within the Chesapeake Bay drainage basin, the United States' largest estuary - SS is one important factor in its habitat degradation (CBF 2012). Data on the source and dynamics of sediment from minimally disturbed watersheds, such as reported here, provide valuable information for management of the Chesapeake Bay and other estuaries similarly impacted by sediments.

\section{Acknowledgements}

We thank Mike Langland and Allen Gellis of the US Geological Survey for comments on early drafts of this manuscript. Comments from two anonymous reviewers also greatly improved the manuscript. Use of trade, product or firm names does not imply endorsement by the US Government.
To submit a comment on this article, please go to

http://mc.manuscriptcentral.com/wej. For further information, please see the Author Guidelines at wileyonlinelibrary.com

\section{References}

Blake, E.S., Kimberlain, T.B., Berg, R., Cangialosi, J.P. and Beven II, J.L. (2013) Tropical Cyclone Report: Hurricane Sandy (AL182012), 22-29 October 2012. National Hurricane Center, NOAA. http://www.nhc.noaa.gov/data/tcr/AL182012_Sandy.pdf. Accessed 10 December 2014.

CBF (Chesapeake Bay Foundation). (2012) The state of the Bay report 2012. http://www.cbf.org/about-the-bay/state-of-thebay/2012-report [accessed 12 December 2014].

Gellis, A.C. (2013) Factors influencing storm-generated suspended-sediment concentrations and loads in four basins of contrasting land use, humid-tropical Puerto Rico. Catena, 104, 39-57.

Giménez, R., Casalí, J., Grande, I., Díez, J., Campo, M.A., ÁlvarezMozos, J. and Goñi, M. (2012) Factors controlling sediment export in a small agricultural watershed in Navarre (Spain). Agric. Water Manage., 110, 1-8.

Halverson, J.B. and Rabenhorst, T. (2013) Hurricane sandy: The science and impacts of a superstorm. Weatherwise, $\mathbf{6 6}$, $14-23$.

Lane, P.N.J. and Sheridan, G.J. (2002) Impact of an unsealed forest road stream crossing: Water quality and sediment sources. Hydrol. Process., 16, 2599-2612.

Leopold, L. B., Wolman, M. G. and Miller, J. P. (1964) Fluvial Processes in Geomorphology. W. H. Freeman, San Francisco, California.

Nadal-Romero, E., Regüés, D. and Latron., J. (2008) Relationships among rainfall, runoff, and suspended sediment in a small catchment with badlands. Catena, 74, 127-136.

Pimental, D., Harvey, C., Resosudarmo, P., Sinclair, K., Kurz, D., McNair, M., Crist, S., Shpritz, L., Fitton, L., Saffouri, R. and Blair, R. (1995) Environmental and economic costs of soil erosion and conservation benefits. Science, 267, 1117-1123.

R Development Core Team. (2013) R: A Language and Environment for Statistical Computing, v. 3.03. R Foundation for Statistical Computing, Vienna, Austria. http://www.R-project.org

Rasmussen, P.P., Gray, J.R., Glysson, G.D. and Ziegler, A.C. (2009) Guidelines and procedures for computing time-series suspended-sediment concentrations and loads from in-stream turbidity-sensor and streamflow data, Book 3, Chapter C4. US Geological Survey Survey Techniques and Methods, 52 p. Available at: http://pubs.usgs.gov/tm/tm3c4/.

Reid, L.M. and Dunne, T. (1984) Sediment production from forest road surfaces. Water Resour. Res., 20, 1753-1761.

Steegen, A., Govers, G., Nachtergaele, J., Takken, I., Beuselinck, L. and Poesen, J. (2000) Sediment export by water from an agricultural catchment in the Loam Belt of central Belgium. Geomorphology, 33, 25-36.

USDA. (2011) RCA Appraisal 2011: Soil and Water Resources Conservation Act. United States Department of Agriculture, Washington, DC. 
Wang, J., Edwards, P.J. and Wood, F. (2013) Turbidity and suspended-sediment changes from stream-crossing construction on a forest haul road in West Virginia, USA. Int. J. For. Eng., 24, 76-90.

Webb, B.W. and Walling, D.E. (1982) The magnitude and frequency characteristics of fluvial transport in a devon drainage basin and some geomorphological implications. Catena, 9, 9-23.
Williams, G.P. (1989) Sediment concentration versus water discharge during single hydrologic events in rivers. J. Hydrol., 111, 89-106.

Wolman, M.G. and Miller, J.P. (1960) Magnitude and frequency of forces in geomorphic processes. J. Geol., 68, 54-74.

Table A1 Suspended sediment and sonde FNU used in SS analyses

\begin{tabular}{|c|c|c|c|c|c|c|c|c|}
\hline STREAM & Date & Time & $\begin{array}{l}\text { Sample } \\
\text { Type }\end{array}$ & $\begin{array}{l}\text { Vol Sampled } \\
\text { (ml) }\end{array}$ & $\begin{array}{l}\text { Vol Filtered } \\
\text { (ml) }\end{array}$ & $\begin{array}{l}\text { SSC } \\
(\mathrm{mg} / \mathrm{L})\end{array}$ & $\begin{array}{l}\text { Sonde } \\
\text { FNU }\end{array}$ & Notes \\
\hline East Branch & $8 / 14 / 2012$ & $11: 00$ & Grab & 1000 & 1000 & 3.0 & 1.8 & Removed as outlier \\
\hline East Branch & $9 / 12 / 2012$ & $10: 58$ & Grab & 1000 & 1000 & 1.5 & 0.2 & Removed because FNU $<1.0$ \\
\hline East Branch & $9 / 18 / 2012$ & $10: 00$ & Grab & 1000 & 500 & 11.3 & 9.8 & \\
\hline East Branch & 9/18/2012 & $11: 10$ & Grab & 1000 & 250 & 47.4 & 39.4 & \\
\hline East Branch & 9/18/2012 & $12: 30$ & Grab & 1000 & 250 & 101.5 & 68.3 & \\
\hline East Branch & $10 / 3 / 2012$ & $13: 15$ & Grab & 1000 & 1000 & 3.7 & 0.4 & Removed because FNU $<1.0$ \\
\hline East Branch & 10/29/2012 & $15: 05$ & Grab & 1000 & 1000 & 5.8 & 5.5 & \\
\hline East Branch & $10 / 29 / 2012$ & $16: 02$ & ISCO & 600 & 500 & 23.9 & 17.7 & \\
\hline East Branch & 10/29/2012 & $17: 02$ & ISCO & 600 & 250 & 94.9 & 73.8 & \\
\hline East Branch & $10 / 29 / 2012$ & $17: 42$ & Grab & 1000 & 250 & 101.2 & 80.6 & \\
\hline East Branch & $10 / 30 / 2012$ & $11: 28$ & Grab & 1000 & 500 & 5.2 & 6.7 & \\
\hline Lower Branch & $7 / 26 / 2012$ & $20: 54$ & & 500 & 450 & 2.4 & 1.0 & Removed because FNU $<1.0$ \\
\hline Lower Branch & $7 / 27 / 2012$ & $15: 54$ & & 500 & 450 & 118.6 & 75.1 & \\
\hline Lower Branch & $7 / 27 / 2012$ & $16: 54$ & & 500 & 450 & 27.7 & 24.7 & \\
\hline Lower Branch & $7 / 27 / 2012$ & $17: 54$ & & 500 & 450 & 14.5 & 17.0 & \\
\hline Lower Branch & $7 / 27 / 2012$ & $18: 54$ & & 500 & 450 & 7.1 & 10.1 & \\
\hline Lower Branch & $7 / 31 / 2012$ & 18:08 & & 500 & 450 & 3.9 & 3.9 & \\
\hline Lower Branch & $7 / 31 / 2012$ & $18: 53$ & & 500 & 450 & 5.1 & 3.4 & \\
\hline Lower Branch & $7 / 31 / 2012$ & $19: 53$ & & 500 & 450 & 3.7 & 3.1 & \\
\hline Lower Branch & $7 / 31 / 2012$ & $20: 53$ & & 500 & 450 & 15.9 & 15.6 & \\
\hline Lower Branch & $7 / 31 / 2012$ & $21: 53$ & & 500 & 450 & 8.2 & 7.6 & \\
\hline Lower Branch & $7 / 31 / 2012$ & $22: 53$ & & 500 & 450 & 7.1 & 6.1 & \\
\hline Lower Branch & $8 / 15 / 2012$ & $0: 01$ & ISCO & 500 & 450 & 43.0 & 29.4 & \\
\hline Lower Branch & $8 / 15 / 2012$ & $1: 01$ & ISCO & 500 & 450 & 14.2 & 11.7 & \\
\hline Lower Branch & $8 / 15 / 2012$ & $2: 01$ & ISCO & 500 & 450 & 8.3 & 8.3 & \\
\hline Lower Branch & $8 / 15 / 2012$ & $3: 01$ & ISCO & 500 & 450 & 4.7 & 4.7 & \\
\hline Lower Branch & $8 / 15 / 2012$ & $4: 01$ & ISCO & 500 & 450 & 3.4 & 3.0 & \\
\hline Lower Branch & 9/6/2012 & $20: 53$ & ISCO & 600 & 500 & 48.6 & 28.6 & \\
\hline Lower Branch & $9 / 6 / 2012$ & $21: 08$ & ISCO & 600 & 500 & 85.9 & 70.3 & \\
\hline Lower Branch & 9/6/2012 & $21: 38$ & ISCO & 600 & 500 & 58.6 & 49.0 & \\
\hline Lower Branch & $9 / 6 / 2012$ & $21: 53$ & ISCO & 600 & 500 & 37.3 & 32.9 & \\
\hline Lower Branch & $9 / 6 / 2012$ & $22: 08$ & ISCO & 600 & 500 & 62.0 & 37.9 & \\
\hline Lower Branch & $9 / 6 / 2012$ & $22: 23$ & ISCO & 600 & 500 & 43.9 & 36.4 & \\
\hline Lower Branch & 9/6/2012 & $22: 38$ & ISCO & 600 & 500 & 28.7 & 25.9 & \\
\hline Lower Branch & $9 / 6 / 2012$ & $22: 53$ & ISCO & 600 & 500 & 28.0 & 22.2 & \\
\hline Lower Branch & $9 / 6 / 2012$ & $23: 08$ & ISCO & 600 & 500 & 18.7 & 18.3 & \\
\hline Lower Branch & $9 / 6 / 2012$ & $23: 23$ & ISCO & 600 & 500 & 16.6 & 15.1 & \\
\hline Lower Branch & $9 / 6 / 2012$ & $23: 38$ & ISCO & 600 & 500 & 14.6 & 13.8 & \\
\hline Lower Branch & $9 / 6 / 2012$ & $23: 53$ & ISCO & 600 & 500 & 12.8 & 13.1 & \\
\hline Lower Branch & $9 / 7 / 2012$ & $0: 08$ & ISCO & 600 & 500 & 10.0 & 11.3 & \\
\hline Lower Branch & $9 / 7 / 2012$ & $0: 23$ & ISCO & 600 & 500 & 9.3 & 8.8 & \\
\hline Lower Branch & $9 / 7 / 2012$ & $0: 38$ & ISCO & 600 & 500 & 7.0 & 7.7 & \\
\hline Lower Branch & $9 / 7 / 2012$ & $0: 53$ & ISCO & 600 & 500 & 6.3 & 7.0 & \\
\hline Lower Branch & $9 / 7 / 2012$ & $1: 08$ & ISCO & 600 & 500 & 5.4 & 6.8 & \\
\hline Lower Branch & 9/7/2012 & $1: 23$ & ISCO & 600 & 500 & 8.7 & 7.0 & \\
\hline Lower Branch & $9 / 7 / 2012$ & $1: 38$ & ISCO & 600 & 500 & 5.7 & 5.7 & \\
\hline Lower Branch & 9/7/2012 & $1: 53$ & ISCO & 600 & 500 & 5.3 & 4.9 & \\
\hline
\end{tabular}


Table A1 Continued

\begin{tabular}{|c|c|c|c|c|c|c|c|c|}
\hline STREAM & Date & Time & $\begin{array}{l}\text { Sample } \\
\text { Type }\end{array}$ & $\begin{array}{l}\text { Vol Sampled } \\
\text { (ml) }\end{array}$ & $\begin{array}{l}\text { Vol Filtered } \\
\text { (ml) }\end{array}$ & $\begin{array}{l}\mathrm{SSC} \\
(\mathrm{mg} / \mathrm{L})\end{array}$ & $\begin{array}{l}\text { Sonde } \\
\text { FNU }\end{array}$ & Notes \\
\hline Lower Branch & $9 / 7 / 2012$ & $2: 08$ & ISCO & 600 & 500 & 7.4 & 4.2 & \\
\hline Lower Branch & 9/7/2012 & $2: 23$ & $\mathrm{ISCO}$ & 600 & 500 & 3.7 & 3.8 & \\
\hline Lower Branch & 9/7/2012 & $2: 38$ & ISCO & 600 & 500 & 4.9 & 3.6 & \\
\hline Lower Branch & $9 / 18 / 2012$ & $8: 29$ & ISCO & 600 & 500 & 15.3 & 4.1 & Removed as outlier \\
\hline Lower Branch & $9 / 18 / 2012$ & $8: 59$ & ISCO & 600 & 500 & 11.6 & 4.4 & Removed as outlier \\
\hline Lower Branch & 9/18/2012 & $9: 10$ & Grab & 1000 & 500 & 5.6 & 5.8 & \\
\hline Lower Branch & 9/18/2012 & $9: 14$ & ISCO & 600 & 500 & 9.9 & 7.1 & \\
\hline Lower Branch & 9/18/2012 & $9: 29$ & ISCO & 600 & 500 & 9.3 & 6.9 & \\
\hline Lower Branch & 9/18/2012 & $9: 44$ & ISCO & 600 & 500 & 8.8 & 7.4 & \\
\hline Lower Branch & 9/18/2012 & $9: 59$ & $\mathrm{ISCO}$ & 600 & 500 & 8.6 & 5.9 & \\
\hline Lower Branch & $9 / 18 / 2012$ & $10: 14$ & ISCO & 600 & 500 & 9.5 & 6.1 & \\
\hline Lower Branch & 9/18/2012 & $10: 29$ & ISCO & 600 & 500 & 10.4 & 7.2 & \\
\hline Lower Branch & 9/18/2012 & $10: 44$ & ISCO & 600 & 500 & 12.6 & 7.9 & \\
\hline Lower Branch & $9 / 18 / 2012$ & $10: 50$ & Grab & 1000 & 500 & 11.8 & 10.3 & \\
\hline Lower Branch & 9/18/2012 & $10: 59$ & ISCO & 600 & 500 & 20.0 & 12.7 & \\
\hline Lower Branch & 9/18/2012 & $11: 14$ & ISCO & 600 & 500 & 34.0 & 25.1 & \\
\hline Lower Branch & 9/18/2012 & $11: 29$ & ISCO & 600 & 500 & 62.8 & 46.1 & \\
\hline Lower Branch & 9/18/2012 & $11: 44$ & ISCO & 600 & 250 & 80.2 & 46.1 & \\
\hline Lower Branch & 9/18/2012 & $11: 59$ & ISCO & 600 & 250 & 104.0 & 52.9 & \\
\hline Lower Branch & 9/18/2012 & $12: 00$ & Grab & 1000 & 250 & 90.6 & 52.9 & \\
\hline Lower Branch & 9/18/2012 & $12: 14$ & ISCO & 600 & 250 & 114.2 & 54.3 & \\
\hline Lower Branch & 9/18/2012 & $12: 29$ & ISCO & 600 & 250 & 154.0 & 76.7 & \\
\hline Lower Branch & 9/18/2012 & $12: 44$ & $\mathrm{ISCO}$ & 600 & 250 & 143.7 & 81.5 & \\
\hline Lower Branch & 9/18/2012 & $12: 59$ & ISCO & 600 & 250 & 106.2 & 69.5 & \\
\hline Lower Branch & 9/18/2012 & $13: 14$ & ISCO & 600 & 250 & 74.6 & 54.3 & \\
\hline Lower Branch & 9/18/2012 & 13:15 & Grab & 1000 & 250 & 65.0 & 54.3 & \\
\hline Lower Branch & 9/18/2012 & $13: 29$ & ISCO & 600 & 250 & 53.6 & 39.9 & \\
\hline Lower Branch & 9/18/2012 & $13: 44$ & ISCO & 600 & 250 & 42.6 & 33.3 & \\
\hline Lower Branch & 9/18/2012 & $13: 59$ & $\mathrm{ISCO}$ & 600 & 250 & 33.9 & 27.9 & \\
\hline Lower Branch & 9/18/2012 & $14: 14$ & ISCO & 600 & 250 & 28.3 & 24.4 & \\
\hline Lower Branch & $9 / 18 / 2012$ & $14: 29$ & ISCO & 600 & 500 & 22.2 & 20.1 & \\
\hline Lower Branch & $10 / 29 / 2012$ & $14: 35$ & Grab & 1000 & 1000 & 1.3 & 0.3 & Removed because FNU $<1.0$ \\
\hline Lower Branch & $10 / 29 / 2012$ & $17: 30$ & Grab & 1000 & 500 & 110.5 & 60.0 & \\
\hline Lower Branch & $10 / 30 / 2012$ & $10: 55$ & Grab & 1000 & 1000 & 6.4 & 8.3 & \\
\hline Upper Branch & $8 / 15 / 2012$ & $12: 22$ & Grab & 1000 & 1000 & 2.8 & 1.7 & Removed as outlier \\
\hline Upper Branch & $9 / 12 / 2012$ & $11: 30$ & Grab & 1000 & 1000 & 0.8 & 0.2 & Removed because FNU $<1.0$ \\
\hline Upper Branch & $9 / 18 / 2012$ & $10: 15$ & Grab & 1000 & 500 & 16.9 & 32.4 & Removed as outlier \\
\hline Upper Branch & 9/18/2012 & $11: 35$ & Grab & 1000 & 500 & 227.9 & 154.5 & \\
\hline Upper Branch & 9/18/2012 & $12: 45$ & Grab & 1000 & 250 & 80.2 & 72.7 & \\
\hline Upper Branch & $10 / 3 / 2012$ & $14: 25$ & Grab & 1000 & 1000 & 0.5 & 0.6 & Removed because FNU $<1.0$ \\
\hline Upper Branch & $10 / 18 / 2012$ & $23: 57$ & ISCO & 600 & 500 & 7.8 & 6.0 & \\
\hline Upper Branch & $10 / 19 / 2012$ & $0: 12$ & ISCO & 600 & 500 & 15.1 & 12.2 & \\
\hline Upper Branch & $10 / 19 / 2012$ & $0: 27$ & ISCO & 600 & 500 & 9.7 & 6.9 & \\
\hline Upper Branch & $10 / 19 / 2012$ & $0: 42$ & ISCO & 600 & 500 & 7.2 & 4.4 & \\
\hline Upper Branch & 10/19/2012 & $0: 57$ & ISCO & 600 & 500 & 5.7 & 5.3 & \\
\hline Upper Branch & 10/19/2012 & $1: 12$ & ISCO & 600 & 500 & 5.7 & 6.8 & \\
\hline Upper Branch & 10/19/2012 & $1: 27$ & ISCO & 600 & 500 & 11.4 & 9.3 & \\
\hline Upper Branch & $10 / 19 / 2012$ & $1: 42$ & ISCO & 600 & 500 & 18.5 & 10.8 & \\
\hline Upper Branch & 10/19/2012 & $1: 57$ & $\mathrm{ISCO}$ & 600 & 500 & 10.7 & 9.4 & \\
\hline Upper Branch & $10 / 19 / 2012$ & $2: 12$ & ISCO & 600 & 500 & 7.3 & 7.0 & \\
\hline Upper Branch & 10/19/2012 & $2: 27$ & ISCO & 600 & 500 & 12.0 & 14.6 & \\
\hline Upper Branch & 10/19/2012 & $2: 42$ & ISCO & 600 & 500 & 16.9 & 10.1 & \\
\hline Upper Branch & 10/19/2012 & $2: 57$ & ISCO & 600 & 500 & 12.9 & 6.9 & \\
\hline Upper Branch & 10/19/2012 & $3: 12$ & ISCO & 600 & 500 & 6.3 & 4.6 & \\
\hline Upper Branch & 10/19/2012 & $3: 27$ & ISCO & 600 & 500 & 5.3 & 3.9 & \\
\hline Upper Branch & 10/19/2012 & $3: 42$ & ISCO & 600 & 500 & 3.9 & 3.3 & \\
\hline
\end{tabular}


Table A1 Continued

\begin{tabular}{|c|c|c|c|c|c|c|c|c|}
\hline STREAM & Date & Time & $\begin{array}{l}\text { Sample } \\
\text { Type }\end{array}$ & $\begin{array}{l}\text { Vol Sampled } \\
\text { (ml) }\end{array}$ & $\begin{array}{l}\text { Vol Filtered } \\
\text { (ml) }\end{array}$ & $\begin{array}{l}\mathrm{SSC} \\
(\mathrm{mg} / \mathrm{L})\end{array}$ & $\begin{array}{l}\text { Sonde } \\
\text { FNU }\end{array}$ & Notes \\
\hline Upper Branch & $10 / 19 / 2012$ & $3: 57$ & ISCO & 600 & 500 & 3.8 & 3.1 & \\
\hline Upper Branch & 10/19/2012 & $4: 12$ & ISCO & 600 & 500 & 3.1 & 3.1 & \\
\hline Upper Branch & 10/19/2012 & $4: 27$ & ISCO & 600 & 500 & 3.2 & 2.7 & \\
\hline Upper Branch & 10/19/2012 & $4: 42$ & ISCO & 600 & 500 & 2.5 & 3.0 & \\
\hline Upper Branch & 10/19/2012 & $4: 57$ & ISCO & 600 & 500 & 2.7 & 2.3 & \\
\hline Upper Branch & 10/19/2012 & $5: 12$ & ISCO & 600 & 500 & 2.2 & 2.1 & \\
\hline Upper Branch & $10 / 19 / 2012$ & $5: 27$ & ISCO & 600 & 500 & 2.1 & 1.9 & \\
\hline Upper Branch & 10/19/2012 & $5: 42$ & ISCO & 600 & 500 & 1.9 & 1.7 & \\
\hline Upper Branch & 10/29/2012 & $14: 56$ & ISCO & 600 & 500 & 7.3 & 2.2 & Removed as outlier \\
\hline Upper Branch & 10/29/2012 & $15: 20$ & Grab & 1000 & 1000 & 10.7 & 5.6 & \\
\hline Upper Branch & 10/29/2012 & $15: 43$ & ISCO & 600 & 500 & 33.3 & 12.4 & Removed as outlier \\
\hline Upper Branch & 10/29/2012 & $16: 43$ & ISCO & 600 & 250 & 96.9 & 60.4 & \\
\hline Upper Branch & 10/29/2012 & $17: 28$ & ISCO & 600 & 250 & 206.0 & 87.6 & \\
\hline Upper Branch & 10/29/2012 & $17: 35$ & Grab & 1000 & 300 & 149.6 & 96.6 & \\
\hline Upper Branch & 10/29/2012 & $17: 49$ & ISCO & 600 & 250 & 181.0 & 118.7 & \\
\hline Upper Branch & 10/29/2012 & $17: 56$ & ISCO & 600 & 250 & 221.5 & 127.1 & \\
\hline Upper Branch & $10 / 30 / 2012$ & $11: 58$ & Grab & 1000 & 1000 & 8.4 & 7.0 & \\
\hline
\end{tabular}

Notes column signifies why a point was removed from analysis. When possible the entire grab or ISCO sample was filtered through a weighed preashed and deionized water rinsed Whatman GFF filter, dried at $105^{\circ} \mathrm{C}$ for $24-48 \mathrm{~h}$ and then reweighed. SSC (mg/L) was the difference between weight of the clean GFF and the weight with the dried sample divided by the volume filtered. During high suspended sediment events, the entire sample could not be filtered - in these instances a subsampled was used. We removed six SSC measurements (two from East, two from Upper and two from Lower) because turbidity readings were $\leq 1.0$ Formazin nephelometric units, (FNU), which was determined a lower boundary for our system. Preliminary inspection of the turbidity-SSC relationships showed a good overlap across branches (Appendix Fig. A2), but additional SSC data points were deemed outliers (East Branch - one outlier, Upper Branch - four outliers and Lower Branch - two outliers) and were removed from the regression models.

Table A2 Results of linear models for the discharge-height relationship

\begin{tabular}{|c|c|c|c|c|c|c|c|c|c|c|}
\hline Site & Storm & Variable & Coefficient Estimate & $P$-value & Adjusted $R^{2}$ & Model $P$-value & RMSE & Up MSPE & LOW MSPE & $\mathrm{BCF}$ \\
\hline \multirow[t]{4}{*}{ East Branch } & \multirow[t]{2}{*}{ Sept } & Intercept & -0.0680 & 0.7439 & \multirow[t]{2}{*}{0.975} & \multirow[t]{2}{*}{0.0083} & \multirow[t]{2}{*}{0.125} & \multirow[t]{2}{*}{33.5} & \multirow[t]{2}{*}{25.1} & \multirow[t]{2}{*}{1.02} \\
\hline & & Height & 6.0650 & 0.0083 & & & & & & \\
\hline & \multirow[t]{2}{*}{ Sandy } & Intercept & -0.8569 & 0.0096 & \multirow[t]{2}{*}{0.984} & \multirow[t]{2}{*}{0.0055} & \multirow[t]{2}{*}{0.113} & \multirow[t]{2}{*}{29.6} & \multirow[t]{2}{*}{22.9} & \multirow[t]{2}{*}{1.02} \\
\hline & & Height & 6.4931 & 0.0055 & & & & & & \\
\hline \multirow[t]{4}{*}{ Upper Branch } & \multirow[t]{2}{*}{ Sept } & Intercept & -0.6515 & 0.0037 & \multirow[t]{2}{*}{0.981} & \multirow[t]{2}{*}{0.0007} & \multirow[t]{2}{*}{0.104} & \multirow[t]{2}{*}{27.0} & \multirow[t]{2}{*}{21.3} & \multirow[t]{2}{*}{1.02} \\
\hline & & Height & 4.1157 & 0.0007 & & & & & & \\
\hline & \multirow[t]{2}{*}{ Sandy } & Intercept & -0.6322 & 0.0447 & \multirow[t]{2}{*}{0.944} & \multirow[t]{2}{*}{0.0188} & \multirow[t]{2}{*}{0.156} & \multirow[t]{2}{*}{43.1} & \multirow[t]{2}{*}{30.1} & \multirow[t]{2}{*}{1.03} \\
\hline & & Height & 4.4707 & 0.0188 & & & & & & \\
\hline \multirow[t]{4}{*}{ Lower Branch } & \multirow[t]{2}{*}{ Sept } & Intercept & -1.4308 & 0.0037 & \multirow[t]{2}{*}{0.916} & \multirow[t]{2}{*}{0.0283} & \multirow[t]{2}{*}{0.171} & \multirow[t]{2}{*}{48.3} & \multirow[t]{2}{*}{32.6} & 1.04 \\
\hline & & Height & 7.7812 & 0.0283 & & & & & & \\
\hline & Sandy & Intercept & -1.7446 & 0.0003 & 0.997 & 0.0010 & 0.046 & 11.1 & 10.0 & 1.00 \\
\hline & & Height & 8.1975 & 0.0010 & & & & & & \\
\hline
\end{tabular}

Results are from models using $\log _{10}$ transformed discharge and height data. RMSE = root mean squared error, MSPE = model standard percentage error and BCF = bias correction factor. Linear regression was used to develop the discharge-height relationships using log $\log _{10}$ transformed height and discharge data. Coefficients from these models were then used to calculate discharge from heights, which were then corrected for backtransformation bias using a smearing retransformation (Rasmussen et al. 2009).

Table A3 Results of linear models for the sonde FNU and SSC relationship

\begin{tabular}{llllllllll}
\hline Site & Estimate & SE & $t$ value & $\operatorname{Pr}(>|t|)$ & $R^{2}$ adj & RMSE & Up MSPE & Low MSPE & BCF \\
\hline East Branch & 1.059 & 0.017 & 62.16 & $7.33 \mathrm{E}-11$ & 0.9952 & 0.070 & 17.44 & 14.85 & 0.987 \\
Upper Branch & 1.108 & 0.015 & 72.14 & $<2 \mathrm{e}-16$ & 0.9979 & 0.100 & 25.90 & 20.57 & 1.053 \\
Lower Branch & 1.083 & 0.009 & 118 & $<2 \mathrm{e}-16$ & 0.9935 & 0.094 & 24.02 & 19.37 & 1.012 \\
\hline
\end{tabular}

RMSE $=$ root mean squared error, MSPE = model standard percentage error, and BCF $=$ bias correction factor. Statistical output for the sonde FNU versus measured SSC. The models fit the data very well (all adjusted $R^{2}>0.99$, all RMSE $\leq 0.10$, all upper MSPE $<26.0$, all lower MSPE $>14.8$ ). The coefficient for $\log _{10}$ FNU for the Upper Branch was 1.108, for the East Branch was 1.059 and for the Lower Branch was 1.083 and the bias correction smearing coefficients were 1.053, 0.987 and 1.012, respectively. Thus, to calculate SSC from the turbidity reading, turbidity (log 10 ) was multiplied by each coefficient, transformed back to original units and then multiplied by each branch's respective smearing coefficient. 

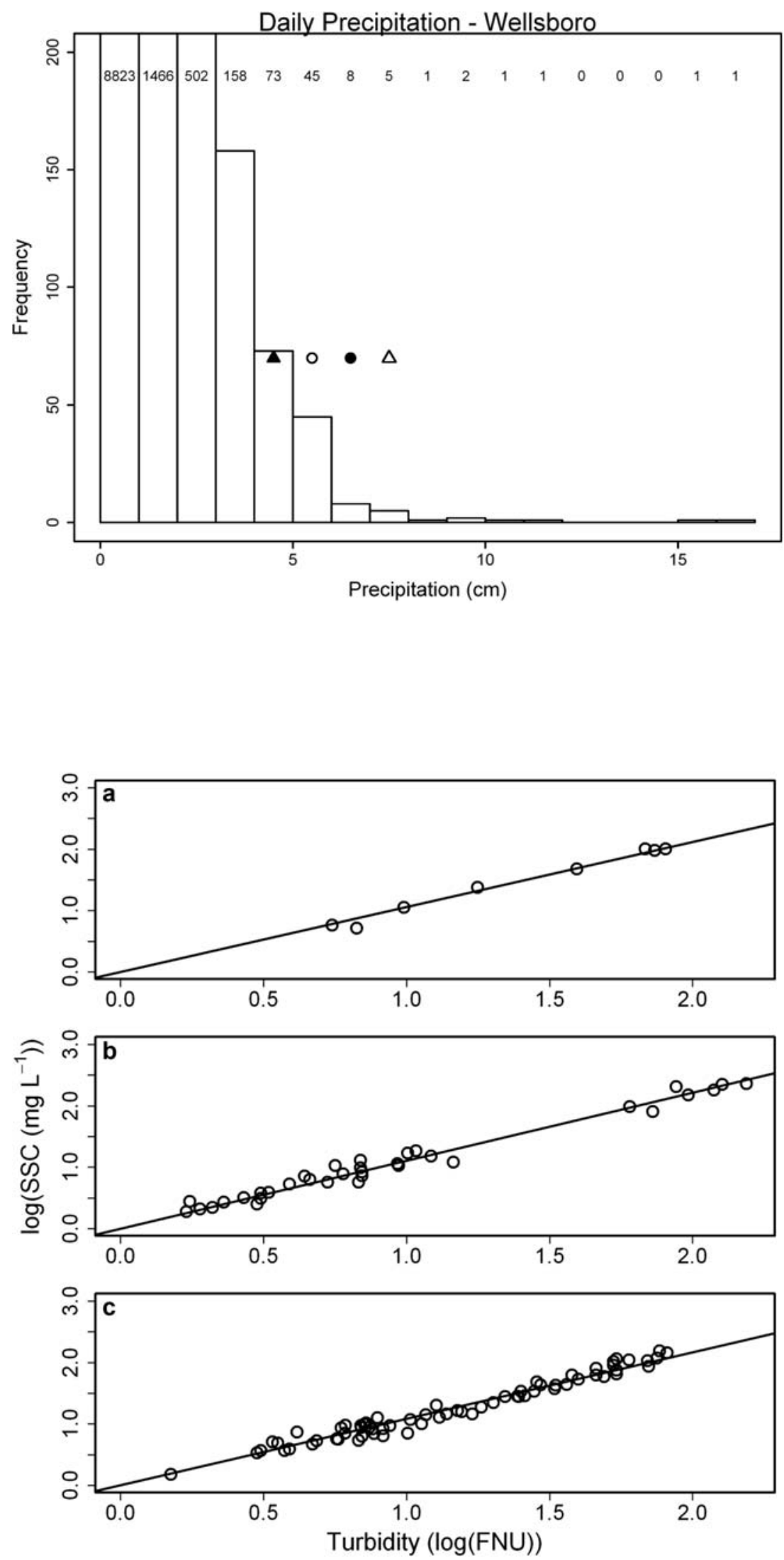

Fig. A1. Histograms of daily precipitation values $(\mathrm{cm})$ from the weather station GHCND:USC00369408 located in Wellsboro, PA, which was 10-12 km southwest of the study location. Data were downloaded from the NOAA National Climatic Data center on 15 January 2014. The data range consisted from 1 January 1926 to 13 January 2014. Open circle indicates total rainfall at the station for Sandy $(5.9 \mathrm{~cm} ; 5.1 \mathrm{~cm}$ on 30 October and 0.4 $\mathrm{cm}$ on 31 October), closed circle indicates total rainfall at the station for the September storm $(6.1 \mathrm{~cm} ; 0.8 \mathrm{~cm}$ on 18 September and $5.3 \mathrm{~cm}$ on 19 September), open triangle indicates total rainfall for Superstorm Sandy at the USGS NARL facility $(7.47 \mathrm{~cm})$, closed triangle indicates total rainfall for the September storm at the NARL facility $(4.80$ $\mathrm{cm})$. Numbers on top of figure indicate the number of recordings in each bin.

Fig. A2. Suspended sediment concentration (SSC) versus Turbidity (FNU, Formazin nephelometric units) used in linear regression models. (a) East Branch (b) Upper Branch and (c) Lower Branch. Note: graph depicts $\log _{10}$ transformed values. 


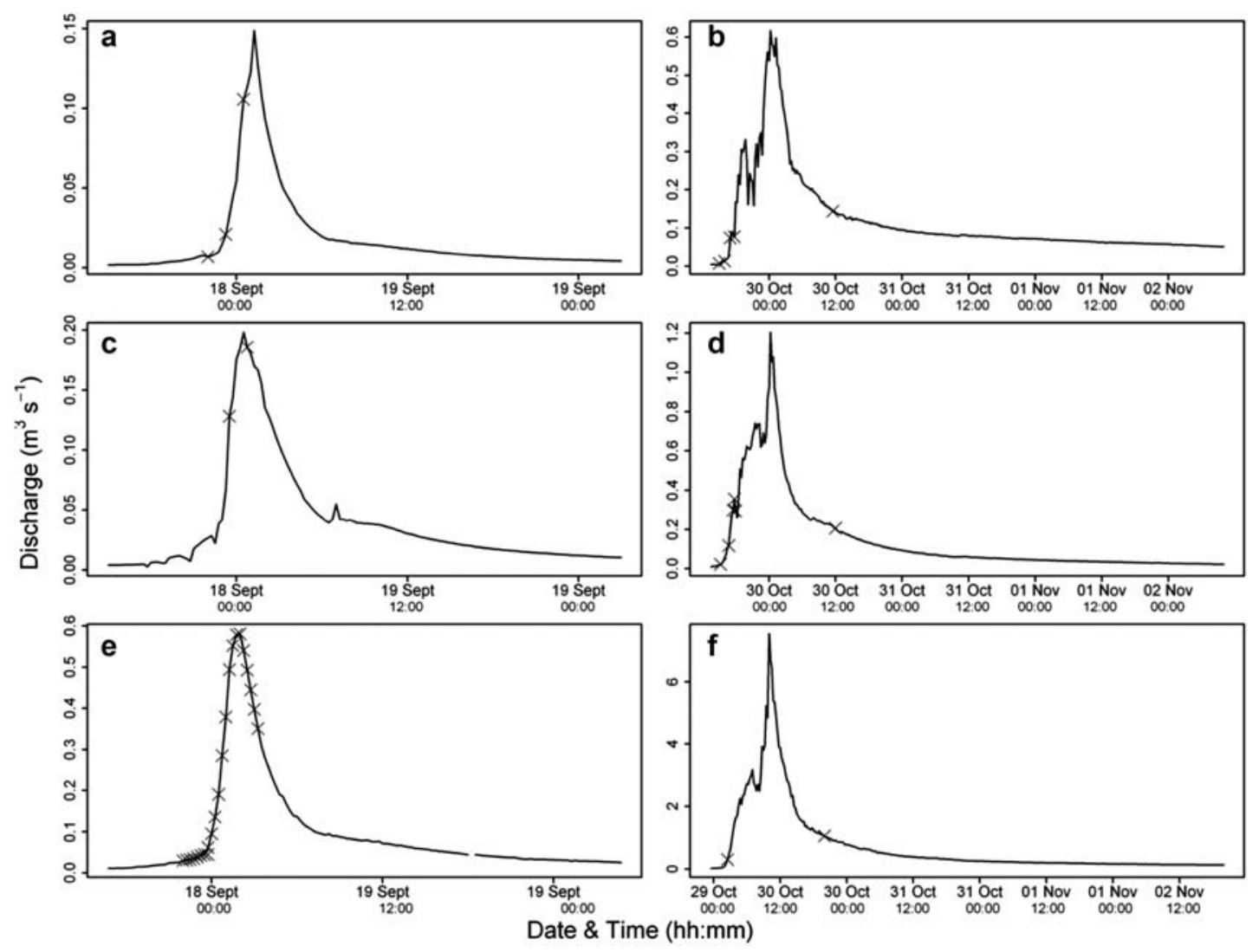

Fig. A3. Close up view of the storm hydrographs - September storm (Left panels) and Superstorm Sandy (Right Panels). (a) East Branch, September storm, (b) East Branch, Superstorm Sandy, (c) Upper Branch, September storm, (d) Upper Branch, Superstorm Sandy, (e) Lower Branch, September storm and (f) Lower Branch, Superstorm Sandy. Xs indicate times when a SSC sample was taken. Additional SSC samples were used in development of the sonde FNU:SSC relationship (see Table A1). 